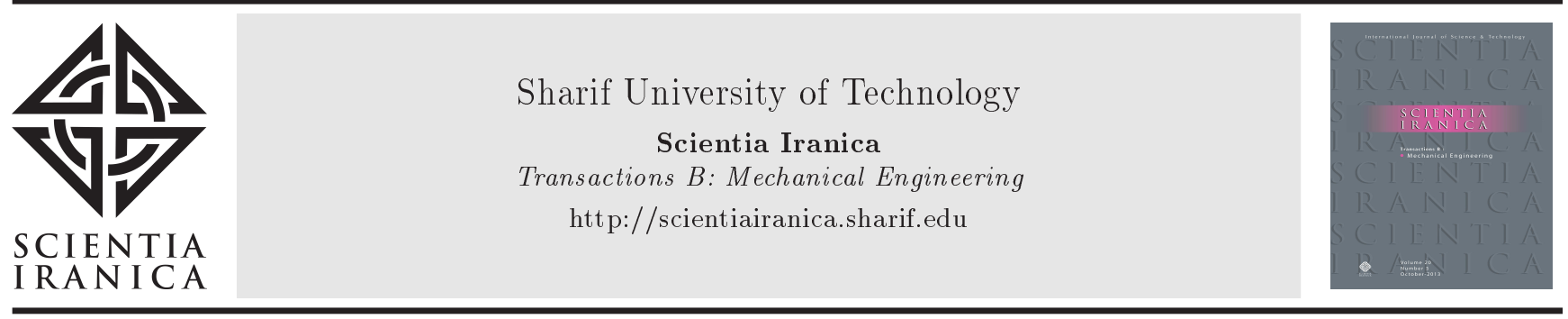

\title{
Effects of welding parameters on penetration depth in mild steel A-TIG welding
}

\author{
M. Kurtulmus* \\ Marmara University, Applied Science High School, Istanbul, Turkey.
}

Received 10 November 2017; received in revised form 11 December 2017; accepted 28 May 2018

\section{KEYWORDS}

A-TIG welding parameters;

Mild steel A-TIG

welding;

A-TIG flux;

A-TIG flux solvent;

A-TIG flux

compositions.

\begin{abstract}
A-TIG welding is a welding method in which TIG welding is conducted by covering a thin layer of activating flux on the weld bead beforehand. The most significant benefit of this process is the gain in weld penetration depth. A-TIG welds were produced on mild steel plates with $\mathrm{TiO}_{2}$ flux. The emphasis of this paper was laid upon introducing the effects of various process parameters, namely welding current, welding speed, powder/acetone ratio of the flux, arc length, and electrode angle on mild steel ATIG welding. The weld penetration depth was measured metallographically. An optimum value was determined for each welding parameter.

(C) 2019 Sharif University of Technology. All rights reserved.
\end{abstract}

\section{Introduction}

TIG welding process produces high joint quality shallow welds [1]. Therefore, only thin sheets can be welded with a single pass. The A-TIG process has been developed to overcome this problem. In this process, a thin flux layer is covered on the joint area prior to welding and dried in several minutes. Then, the conventional TIG welding is done [1]. The use of the fluxes in A-TIG welding increases penetration and productivity due to the reduction in the number of weld passes required to make the joint. This welding process is successively applied to austenitic stainless steel [2], ferritic stainless steel [3], and mild steel [4]. The number of published papers about mild steel ATIG welding applications are less than 10 [4-10].

The welding parameters determine the weld bead geometry and weld penetration depth in an electric arc welding process [11]. There are several studies in the literature about the effects of welding parameters on weld spot size in electric spot welding of mild steel

\footnotetext{
*.E-mail address: memduhk@marmara.edu.tr
}

sheets [12]. Although many research studies have been carried out on A-TIG welding of austenitic stainless steel [13], there are no papers that explain the effects of welding parameters on A-TIG mild steel in detail. The studies on mild steel A-TIG welding applications have shown the importance of welding current $[5,7]$, the flux chemical composition [4], the acetone ratio of the flux [4], the arc length [4], and the welding speed [7] in weld penetration. Therefore, the welding current, welding speed, arc length, electrode angle, and composition of the welding flux are considered as the A-TIG welding parameters. In the present study, the effects of these welding parameters on mild steel A-TIG welding penetration were investigated by macrostructure examinations.

\section{Materials and methods}

A standard St42 plate in normalized condition was used for the current effect investigation. The plate was machined into $120 \times 250 \times 10 \mathrm{~mm}$ rectangular plates . The plates were cleaned with acetone and then, dried in still air. Pure $\mathrm{TiO}_{2}$ powder was mixed with acetone into a paste and painted on the surface of the plates by a brush. Then, the plates were kept in still air for 15 
Table 1. Welding parameters and their ranges.

\begin{tabular}{llc}
\hline \multicolumn{1}{c}{ Welding Parameter } & \multicolumn{1}{c}{ Unit } & Range \\
\hline Welding current & $\mathrm{A}$ & $70-210$ \\
Welding speed & $\mathrm{mm} / \mathrm{sec}$ & $8-24$ \\
Arc length & $\mathrm{mm}$ & $1-5$ \\
$\mathrm{TiO}_{2} /$ acetone volume ratio & $\%$ & $14-34$ \\
Electrode angle & Deg. & $70-100$ \\
\hline
\end{tabular}

minutes to evaporate the acetone in the paste, leaving the flux on the surface before welding.

Bead-on plate welds were made by a conventional TIG machine to investigate the effect of welding parameters on the depth of penetration. A $2 \%$ thoriated tungsten electrode rod with $2.4 \mathrm{~mm}$ of diameter was used in welding. The shielding gas was pure argon. The shielding gas flow rate was kept constant at 12 litter/minute.

The welding parameter variables in this research are welding current, welding speed, arc length, $\mathrm{TiO}_{2} /$ acetone volume ratio, and electrode angle. The welding parameters and the ranges employed for them are given in Table 1 . In every welding test set, only one parameter varies. For every welding parameter condition, both A-TIG and TIG welds were produced.

Three weld cross-sections were taken at several locations along the length of each bead on plate weld. Samples for metallographic examination were prepared using standard procedures including mounting, grinding, polishing, and etching with nital. Macrostructures of the joints were examined by an optical microscope. The cross-sections of the welds were photographed. The photographs were taken by an Olympus PME 3 apparatus. The dimension of the penetration depth was measured on cross-sectional macrographs of the weld. For each welding condition, three measurements were made and the average value was calculated. The weld penetration depth of A-TIG weld was named $D_{\text {A-TIG }}$ and the depth of TIG weld $D_{\text {TIG }}$. Then, the penetration depth ratios $\left(D_{\mathrm{A}-\mathrm{TIG}} / D_{\mathrm{TIG}}\right)$ of the welds were calculated for each welding condition.

\section{Results}

Figure 1 shows the cross-sections of TIG and A-TIG welds. In these welds, the constant values of 0.33 for powder/acetone volume ratio, $10 \mathrm{~mm} / \mathrm{s}$ for welding speed, 80 degrees for electrode angle, and $3 \mathrm{~mm}$ for arc length were maintained. Two different weld currents were used: $120 \mathrm{~A}$ and $180 \mathrm{~A}$. The welds with the same parameters gave roughly equal weld widths. ATIG welds had greater weld penetrations than the TIG welds. The first results indicated the effectiveness of the welding flux.

Figure 2 shows the effect of the $\mathrm{TiO}_{2} /$ acetone
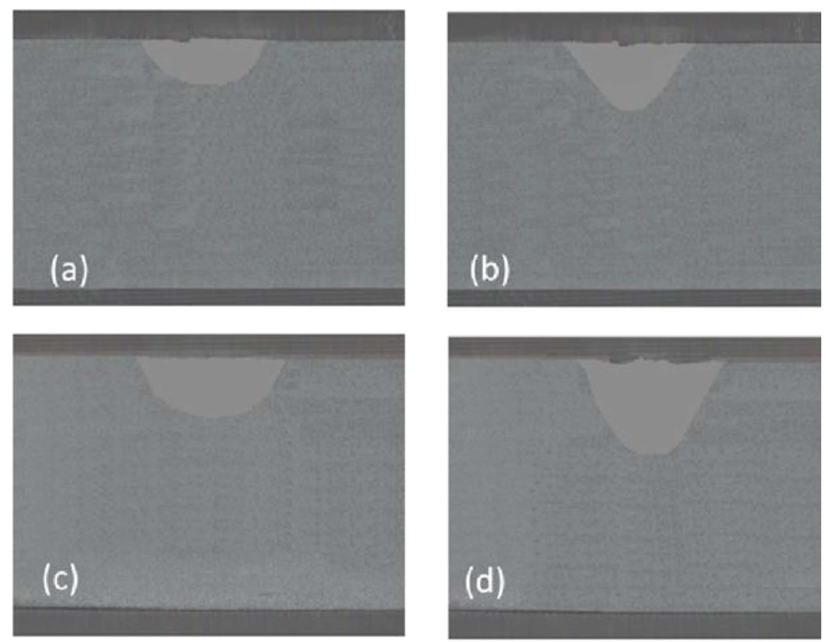

Figure 1. Macrostructures of TIG and A-TIG welds: (a) TIG 120 A, (b) A-TIG 120 A, (c) TIG 180 A, and (d) A-TIG 180 A.

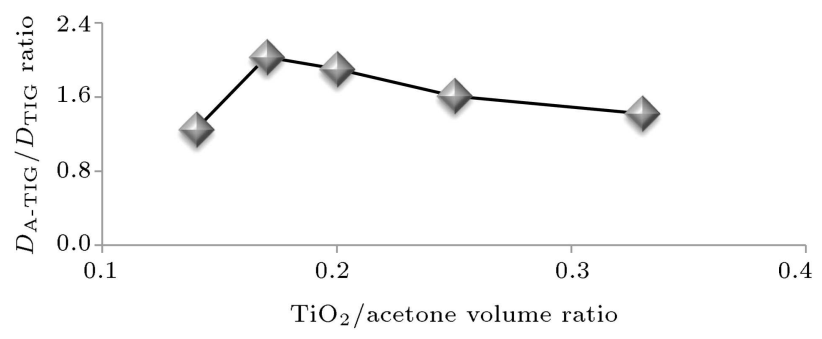

Figure 2. Effect of the $\mathrm{TiO}_{2} /$ acetone volume ratio on weld penetration depth ratio.

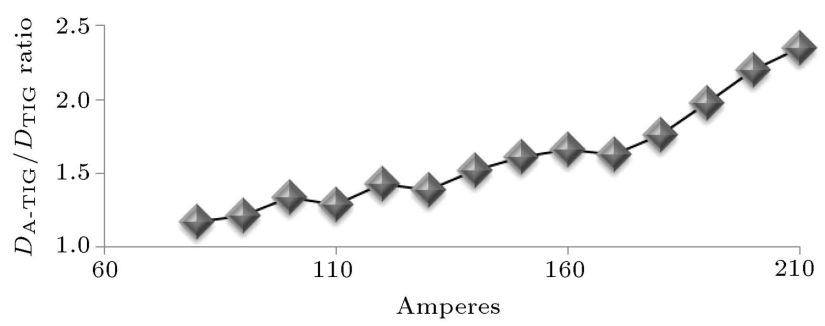

Figure 3. The relation between weld penetration depth ratio and the weld current.

volume ratio on weld penetration depth ratio. In these welds, the welding current was $180 \mathrm{~A}$, the electrode angle was 80 degrees, the welding speed was is $10 \mathrm{~mm} / \mathrm{s}$, and the arc length was $3 \mathrm{~mm}$. The $\mathrm{TiO}_{2} /$ acetone volume ratio had a distinct effect on weld penetration. The $D_{\text {A-TIG }} / D_{\text {TIG }}$ first increased with $\mathrm{TiO}_{2} /$ acetone volume ratio up to 0.17 and then, showed a declining trend.

Figure 3 shows how the penetration depth ratio of the welds ( $\left.D_{\mathrm{A}-\mathrm{TIG}} / D_{\mathrm{TIG}}\right)$ varies with the welding current. In these welds, the welding speed was $10 \mathrm{~mm} / \mathrm{s}$, the powder/acetone volume ratio was 0.17 , the arc length was $3 \mathrm{~mm}$, and the electrode angle was 80 degrees. In electric arc welding operations, the increase in welding current caused a higher weld 


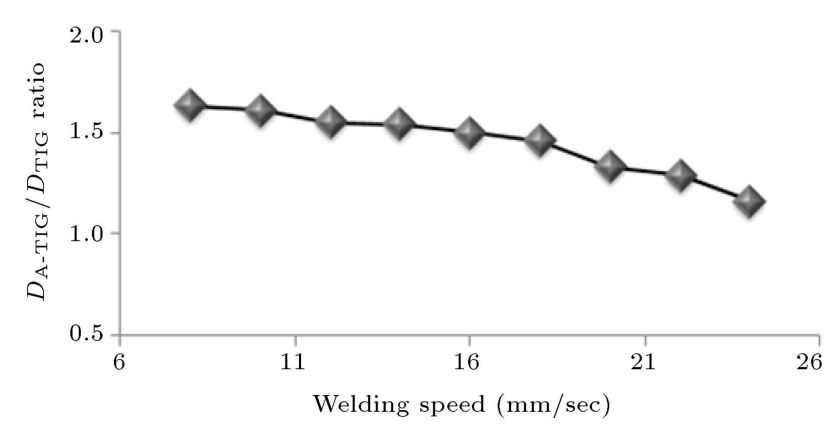

Figure 4. The relation between weld penetration depth ratio and the welding speed.

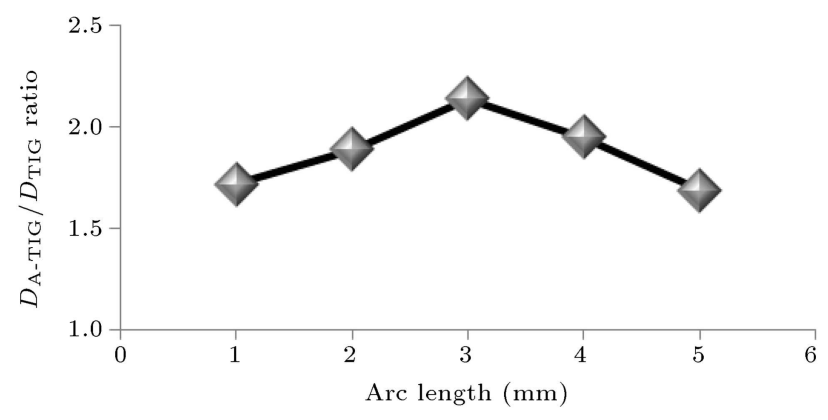

Figure 5. Effect of the arc length on weld penetration depth ratios of A-TIG and TIG welds.

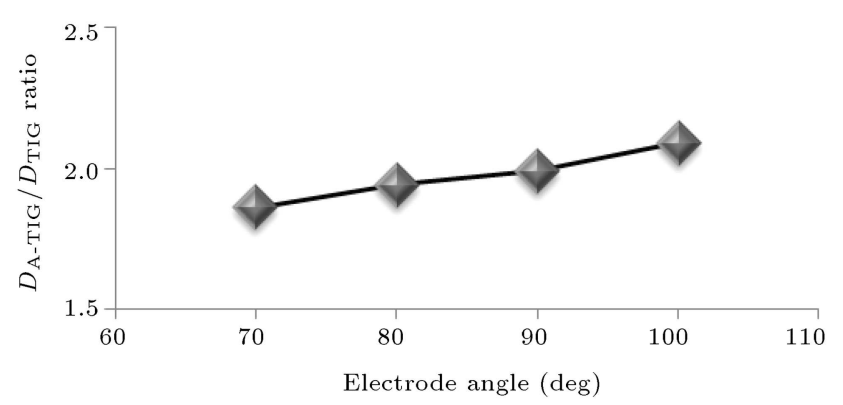

Figure 6. The relation between weld penetration depth ratio and the electrode angle.

energy, which increased the weld penetration depth. Figure 3 indicates that the penetration depth of the welds increased with the welding current as expected.

Figure 4 shows the effect of welding speed on weld penetration depth ratio. In these welds, the welding current was $150 \mathrm{~A}$, the powder/acetone volume ratio was 0.17 , the arc length was $3 \mathrm{~mm}$, and the electrode angle was 80 degrees. The $D_{\text {A-TIG }} / D_{\text {TIG }}$ ratio decreased with the speed.

Figure 5 shows the effect of arc length on weld penetration ratios of mild steel A-TIG and TIG welding processes. In these welds, the welding current was $180 \mathrm{~A}$, the powder/acetone volume ratio was 0.17 , the welding speed was $10 \mathrm{~mm} / \mathrm{s}$, and the electrode angle was 80 degrees. The penetration increased with the arc length. The penetration ratio reached a peak value at $3 \mathrm{~mm}$ of arc length and then, it decreased.

Figure 6 indicates the relation between the weld penetration depth ratio and the electrode angle. In these welds, the welding current was $180 \mathrm{~A}$, the powder/acetone volume ratio was 0.17 , the welding speed was $10 \mathrm{~mm} / \mathrm{s}$, and the arc length was $3 \mathrm{~mm}$. The penetration ratio increased with the electrode angle.

\section{Discussion}

The photographs in Figure 1 prove that A-TIG welds had greater weld penetration depths than the TIG welds, which were welded with the same welding current. This difference was due to the welding flux. Dissociation of the $\mathrm{TiO}_{2}$ particles of the flux occurred [14] during the A-TIG welding operation, which increased the active surface tension in the weld pool [15]. In this case, the liquid metal movement in the pool became vertical [16]. Thus, the vertical liquid metal movement in the A-TIG weld pool increased the penetration depth [17].

Figure 2 indicates the importance of $\mathrm{TiO}_{2} /$ acetone volume ratio. After the evaporation of the acetone, residual $\mathrm{TiO}_{2}$ powder was left on the plate. Thickness of the residual powder directly depended on the $\mathrm{TiO}_{2} /$ acetone volume ratio [18]. The thickness of the powder increased with the $\mathrm{TiO}_{2}$ /acetone volume ratio. The lowest penetration ratio was obtained for the 0.14 flux ratio. In this welding condition, minimum amount of $\mathrm{TiO}_{2}$ dissociation occurred during welding. A small amount of oxygen was dissolved in the weld pool; thus, increase in the surface tension was also small. Therefore, a shallow weld was produced in the A-TIG welding operation. The oxygen transferred to the weld pool increased with the thickness of the residual $\mathrm{TiO}_{2}$ layer. The maximum $D_{\mathrm{A}-\mathrm{TIG}} / D_{\mathrm{TIG}}$ ratio was obtained at the 0.17 flux ratio. This flux ratio gave the optimum amount of oxygen atoms in the pool. When the oxygen amount exceeded the optimal limit, a thin oxide layer formed on the pool surface, which decreased the weld penetration [19]. The fall of the penetration thickness happened as the $\mathrm{TiO}_{2} /$ acetone volume ratio exceeded the 0.17 ratio limit.

The increase in the weld current led to a higher level of energy in the weld zone. This great energy in put enlarged the weld geometry [11]. The weld width and the weld penetration depth increased as shown in Figure 1. However, the growths in weld penetration depth with the weld current were not equivalent for TIG and A-TIG welds. The $\left(D_{\mathrm{A}-\mathrm{TIG}} / D_{\mathrm{TIG}}\right)$ was 1.15 at $80 \mathrm{~A}, 1.32$ at $130 \mathrm{~A}$, and 1.78 at $180 \mathrm{~A}$ as shown in Figure 3. The activating flux effect on the weld penetration became pronounced with the current. The melted and vaporized activating flux amount increased with the current, and this enlarged the vertical movement in the weld pool and the arc constriction effect of the flux [1]. Therefore, the penetration of A-TIG welds increased much more than that of the TIG welds. 
The slope of the curve increased beyond 170 A. Similar results were obtained in A-TIG welding of high alloyed steels [18].

In electric arc welding operations, increase in welding speed leads to a lower weld energy input, which decreases the weld penetration depth [11]. The weld pool size and solidification time of the weld get smaller with the welding speed. At a low welding speed, the weld pool solidifies in a longer period, which causes a high amount of $\mathrm{TiO}_{2}$ dissociation in A-TIG welds. Therefore, more liquid metal motion and deep penetration can be obtained. The advantages of A-TIG welds are dissolved at high welding speeds as shown in Figure 4.

Figure 5 shows the effect of the weld arc length on A-TIG welding. When the arc length is very short, the speed of electrons in the arc is low. The bombing effect of the electrons is low when the arc length is short and heating of the weld pool is small. This welding condition produces a shallow weld. The bombing effect of the electrons becomes bigger by extending the arc length from $1 \mathrm{~mm}$ to $3 \mathrm{~mm}$ as shown in Figure 5. The electron speed, the anode diameter, and the temperature of the anode increase when the arc length exceeds $3 \mathrm{~mm}$ [19]. Then, the penetration decreases because the anode diameter enlarges [20] and the efficiency of the welding heat transfer to the work piece decreases [11].

The electrode angle in A-TIG welding process affects the diameter of the weld plasma column diameter [21]. The plasma column diameter, arc pressure, and current density at the anode root increase with the electrode angle $[22,23]$. The penetration depth increases parallel to the arc pressure and current density as shown in Figure 6.

\section{Conclusions}

The effects of welding current, welding speed, $\mathrm{TiO}_{2}$ powder/acetone ratio of the flux, arc length, and electrode angle on penetration of mild steel A-TIG welding were investigated. The results clearly showed that all these parameters could increase the penetration capability of the welding process. The principal results may be summarized as follows:

- The welding current increases the weld penetration depth more in A-TIG welding than in TIG welding;

- The welding speed continuously decreases the weld penetration depth in A-TIG welding;

- The electrode angle increases the weld penetration depth;

- The best penetration depth was obtained with the $0.17 \mathrm{TiO}_{2}$ powder/acetone ratio;
- The $3 \mathrm{~mm}$ arc length gave the best penetration depth.

\section{References}

1. Ahmed, N., New Developments in Advanced Welding, Woodhead Publishing Limited, Abington (2005).

2. Choudhary, S. and Duhan, R. "Effect of activated flux on properties of SS 304 using TIG welding", Inter. J. Eng. Trans. B., 28, pp. 290-295 (2015).

3. Azevedoa, A.G.L., Ferraresia, V.A.J., and Farias, J.P. "Ferritic stainless steel welding with the A-TIG process", Weld. Inter., 24, pp. 571-578 (2010).

4. Fan, D., Zhang, R., Gu, Y., and Ushio, M. "Effect of flux on A-TIG welding of mild steels", Trans. Join. Weld. Res. Ins., 30, pp. 35-40 (2001)

5. Pan, W. and Shi, K. "Research on the effects of technical parameters on the molding of the weld by A-TIG welding", Trans. Join. Weld. Res. Ins., 40, pp. 37-9 (2011)

6. Cheng, H.K., Tseng, K.T., and Chou, C.P. "Effect of activated TIG flux on performance of dissimilar welds between mild steel and stainless steel", Key Eng. Mater., 479, pp. 74-80 (2011)

7. Vikesh, P., Randhawa, J., and Suri, N.M. "Effect of A-TIG welding process parameters on penetration in mild steel plates", Int. J. Mecha. Indust. Eng., 3, pp. 2231-2247 (2013).

8. Tathgir, S., Bhattacharya, A., and Bera, T.K. "Influence of current and shielding gas in $\mathrm{TiO}_{2}$ flux activated TIG welding on different graded steels", Mater. Manuf. Proces., 30, pp. 1115-112 (2015).

9. Singh, E.B. and Simgh, E.A. "Performance of activated TIG process in mild steel welds", J. Mecha. Civil Eng., 12, pp. 1-5 (2015).

10. Tathgir, S. and Bhattacharya, A. "Activated-TIG materials and manufacturing processes welding of different steels: Influence of various flux and shielding gas", Mater. Manuf. Proces. J., 31, pp. 335-342 (2016).

11. Cary, H.B. and Helzer, S., Modern Welding Technology, 6th Edn., Prentice Hall, NewYork (2004).

12. Akkaş, N., Ferik, E., İlhan, E. and Aslanlar, S. "The effect of welding current on nugget sizes in resistance spot welding of SPA-C steel sheets used in railway vehicles", 130, pp. 142 (2016).

13. Kumar, R. and Bharathi, S. "A review study on A-TIG welding of $316(\mathrm{~L})$ austenitic stainless steel", International Journal of Emerging Trends in Science and Technology, 2, pp. 2066-2072 (2015).

14. Zhang, J.R., Pan, H.I., and Katayama, S. "The mechanism of penetration increase in A-TIG welding", Frontiers Mater. Sci., 5, pp. 109-118 (2011).

15. Berthier, A., Paillard, P., Carin, M., Valensi, F., and Pellerin, S. "TIG and A-TIG welding experimental investigations and comparison to simulation. Part 1: Identification of Marangoni effect", Sci. Technol. Weld. Join., 17, pp. 609-615 (2012). 
16. Zhao, Y., Shi, Y., and Lei, Y. "The study of surfaceactive element oxygen on flow patterns and penetration in A-TIG welding", Metall. Mater. Trans. B, 37, pp. 485-493 (2006).

17. Xu, Y.L., Dong, Z.B., Wei, Y.H., and Yang, C.L. "Marangoni convection and weld shape variation in ATIG welding process", Theo. App. Fract. Mecha., 48, pp. $178-186$ (2007).

18. Ruckert, G., Huneau, B., and Marya, S. "Optimizing the design of silica coating for productivity gains during the TIG welding of 304L stainless steel", Mater. Des., 28, pp. 2387-2393 (2007).

19. Modenesi, P.J., Neto, P.C., Apolinario, E.R., and Dias, K.B. "Effect of flux density and the presence of additives in ATIG welding of austenitic stainless steel", Weld. Inter., 29, pp. 425-432 (2015).

20. Maduraimuthu, V., Vasudevan, M., Muthupandi, V., Bhaduri, A.K., and Jayakumar, T. "Effect of activated flux on the microstructure, mechanical properties, and residual stresses of modified $9 \mathrm{Cr}-1 \mathrm{Mo}$ steel weld joints", Metall. Mater. Trans. B., 43, pp. 123-132 (2012).

21. Zhang, Z.D., Liu, L.M., Shen, Y., and Wang, L. "Welding of magnesium alloys with activating flux", Sci. Techno. Weld. Join., 10, pp. 737-743 (2005).

22. Shyu, S.W., Huang, H.Y., Tseng, K.H., and Chou,
C.P. "Study of the performance of stainless steel ATIG welds", J. Mater. Eng. Perfor., 7, pp. 193-201 (2008).

23. Hiraoka, K., Okada, A., and Inagaki, M. "Effect of electrode geometry on maximum arc pressure in GTA weldments", J. Japan. Weld. Soci., 3, pp. 10-16 (1985).

\section{Biography}

Memduh Kurtulmus received his BSc degree in Metal Working Field in 1994 from Marmara University. He finished his MSc studies in 1998 and PhD studies in 2005 at the same university. Both of his theses were in welding technology field. He received a Level 3 certificate of Non-Destructive Testing Processes from Turkish Standards Institute in 2003. Moreover, he received a BSc degree in Mechanical Engineering from Istanbul Newport University. He became an International Welding Engineer at Romanian Welding Institute in 2006. He worked in the Technical Engineering Faculty at Marmara University as a Research Assistant during 1994-2006. He became an Assistant Professor in the same faculty in 2006. He is an expert in maintenance welding and NDT processes. His 52 papers have been printed in journals and symposium proceedings. 